\title{
Characterization and Activity Change of Farnesol Dehydrogenase in Black Rot Fungus- infected Sweet Potato
}

\author{
Hiromasa INOUE, * Hiroko TsuJI and Ikuzo URITANI* \\ Laboratory of Biochemistry, Faculty of Agriculture, \\ Nagoya University, Chikusa, Nagoya 464, Japan
}

Received August 31, 1983

\begin{abstract}
NADP-dependent farnesol dehydrogenase was isolated from black rot fungus-infected sweet potato root tissue and purified almost to homogeneity with several purification steps including Toyopearl HW-60 (S) chromatography. The enzyme was estimated to have a molecular weight of 90,000 and consists of two identical subunits. trans,trans-Farnesol was oxidized to trans,transfarnesal at the highest level among various kinds of alcohol in the presence of NADP by the enzyme, but the enzyme showed broad substrate specificity. The SH-group in the enzyme participated in its activity. The enzyme was present in small amounts in fresh tissue, but in response to the infection the activity was increased, accompanied with the accumulation of furanosesquiterpenoids. The activity was increased also in response to cut injury, although in a lesser amount.
\end{abstract}

When infected by the black rot fungus, Ceratocystis fimbriata and some other pathogens, various kinds of sesquiterpenoids such as ipomeamarone ${ }^{1,2)}$ are accumulated in the infected region of sweet potato root tissue ${ }^{3,4)}$ and play a role in protecting the tissue from microbial penetration as phytoalexins. ${ }^{5,6)}$ The in vivo and in vitro experimental results demonstrated that the mevalonate pathway, the route from acetyl $\mathrm{CoA}$ to farnesol was involved in the biosynthetic pathway of sesquiterpenoids as the first half step, and the enzymes in this step were induced in response to the infection, prior to sesquiterpenoid accumulation. ${ }^{7,8)}$

A few experimental observations ${ }^{9 \sim 12)}$ have been obtained to elucidate the second half step of the pathway, the route from trans, trans$(t, t$-)farnesol to furano-sesquiterpenoids such as dehydroipomeamarone, ${ }^{13)}$ ipomeamarone $^{1,2)}$ and ipomeamaronol. ${ }^{14,15)}$ Since Oguni and Uritani ${ }^{9)}$ indicated that ${ }^{14} \mathrm{C}$-farnesol was efficiently converted to ${ }^{14} \mathrm{C}$-ipomeamarone in black rot fungus-infected tissue, we assumed that the initial step of farnesol metabolism might be the dehydration of farnesol to farnesal, and recognized the presence of NADP-dependent farnesol dehydrogenase in diseased tissue.

This paper deals with the purification and characterization of the above farnesol dehydrogenase in diseased tissue and the change of the activity in sweet potato root tissue in response to black rot fungus infection and cut injury.

\section{MATERIALS AND METHODS}

Materials. Roots of sweet potato (Ipomoea batatas Lam., cv. Norin No. 1) were harvested at the Kariya Farm, Aichi Prefecture in the autumn and stored at $13 \pm 1^{\circ} \mathrm{C}$ until used.

* Present address: Laboratory of Oral Bacteriology, Kyushu Dental College, Kitakyushu, Fukuoka 803, Japan and Faculty of Home Economics, Nagoya Women's University, Shioji-cho, Mizuho, Nagoya 467, Japan, respectively.

Abbreviations: farnesol or $t, t$-farnesol, trans,trans-farnesol; $c$, $t$-farnesol, cis,trans-farnesol; DTT dithiothreitol. This work was presented at the Annual Meeting of the Agricultural Chemical Society of Japan, Fukuoka, April 1980. 
The farnesol purchased (Fluka AG.Buchs SG, Switzerland) was composed of the trans, trans-form and the cis, trans-form, which were separated by TLC using $n$ hexane-EtOAc $(7: 3, \mathrm{v} / \mathrm{v})$ as the developing solvent.

$t, t$-Farnesal was synthesized with the oxidation of $t, t$ farnesol by activated $\mathrm{MnO}_{2} \cdot{ }^{16}$ )

Preparation of crude enzyme solutions from diseased tissue for purification and for analysis of changes with time. Sweet potato roots were perpendicularly cut into slices $(2 \mathrm{~cm}$ thick), which were inoculated on the cut surfaces with a spore suspension of Ceratocystis fimbriata Ell. et Halst., and incubated at $29^{\circ} \mathrm{C}$. under high humidity. After $48 \mathrm{hr}$ of incubation, non-infected tissue ( 1 to $1.5 \mathrm{~mm}$ thick) adjacent to the infected region was collected and cut finely. The tissue pieces $(80 \mathrm{~g})$ were homogenized at about $2^{\circ} \mathrm{C}$ in $160 \mathrm{ml}$ of $100 \mathrm{~mm}$ potassium phosphate buffer ( $\mathrm{pH} \mathrm{7.5)}$ containing $0.5 \mathrm{M}$ sucrose, $10 \mathrm{~mm}$ mercaptoethanol, $10 \mathrm{~mm}$ EDTA and $10 \%(16 \mathrm{~g})$ Polyclar AT with a blender three times each for $15 \mathrm{sec}$. The homogenate was squeezed through two layers of nylon gauze, the filtrate centrifuged at $300 \times g$ for $10 \mathrm{~min}$. The supernatant solution was passed through a Sephadex G-25 column preequilibrated with $20 \mathrm{~mm}$ potassium phosphate buffer ( $\mathrm{pH} \mathrm{8.0)}$ containing $0.5 \mathrm{M}$ sucrose and $1 \mathrm{~mm}$ dithiothreitol (DTT) (called standard buffer), and eluted with standard buffer yielding the protein fraction, which was centrifuged at $10,000 \times g$ for $20 \mathrm{~min}$, and the supernatant solution was used as the crude enzyme solution.

For the analysis of the course of infection or injury, the tissue slices with or without inoculation were incubated, then $10 \mathrm{~g}$ of adjacent non-infected tissue pieces were used to prepara the crude enzyme solution, in the same way as shown above.

Enzyme purification. The crude enzyme solution was precipitated by 40 to $64 \%$ saturation of ammonium sulfate and the precipitate was collected by centrifugation and suspended in $5 \mathrm{ml}$ of standard buffer. The suspension was passed through Sephadex G-25 column previously equilibrated with the above buffer. The effluent was applied to a DE- 52 column $(3.0 \times 6.0 \mathrm{~cm})$ that had been equilibrated with standard buffer. After passing $20 \mathrm{ml}$ of the buffer, the farnesol dehydrogenase-containing fraction was eluted with a linear gradient of $150 \mathrm{ml}$ each of standard buffer and the above buffer containing in addition $0.15 \mathrm{M} \mathrm{KCl}$.

This fraction was concentrated by ultrafiltration using an Amicon PM30 membrane up to $5 \mathrm{ml}$, changing the buffer to $20 \mathrm{~mm}$ potassium phosphate buffer ( $\mathrm{pH} 8.0$ ) containing $0.2 \mathrm{M} \mathrm{KCl}$ and $1 \mathrm{~mm}$ DTT. The concentrate was applied to a column $(2.6 \times 38.0 \mathrm{~cm})$ of Toyopearl HW- 60 (S) (Toyo Soda Co.) preequilibrated with the same buffer and eluted with the above buffer by an HPLC pump (Hitachi 635) at the rate of $1 \mathrm{ml}$ per min. The fraction containing the enzyme was concentrated by ultrafiltration as above. During concentration the buffer was changed to the buffer without $0.2 \mathrm{M} \mathrm{KCl}$. The concentrate was applied to a $2^{\prime}, 5^{\prime}$-ADP-Sepharose $4 \mathrm{~B}$ column $(1.0 \times 3.6 \mathrm{~cm})$ previously equilibrated with $20 \mathrm{~mm}$ phosphate buffer containing $1 \mathrm{~mm}$ DTT and eluted with a linear gradient of $10 \mathrm{ml}$ each of the above buffer and the same buffer containing in addition $3 \mathrm{M} \mathrm{KCl}$. The enzyme solution thus obtained was concentrated by ultrafiltration up to $1 \mathrm{ml}$, changing the buffer to $20 \mathrm{~mm}$ phosphate buffer ( $\mathrm{pH} 8.0$ ) containing $1 \mathrm{~mm}$ DTT. Finally, the enzyme-containing concentrate was stored at $-80^{\circ} \mathrm{C}$ until used, and diluted by the above buffer for the enzymatic assay.

Enzyme assay. The reaction medium was composed of $20 \mathrm{~mm}$ potassium phosphate buffer $(\mathrm{pH} 8.0$ ) with or without $0.5 \mathrm{M}$ sucrose, $0.3 \mathrm{~mm} t, t$-farnesol in $5 \mu$ l acetone, an aliquot of the enzyme solution, and $0.5 \mathrm{~mm}$ NADP in $0.3 \mathrm{ml}$ of final volume. Prior to the enzymatic reaction, the medium without NADP was incubated at $25^{\circ} \mathrm{C}$ for about 5 min until a constant value for the absorbance at $340 \mathrm{~nm}$ was obtained. Then the reaction was started by adding the NADP solution. The initial increase in the absorbance was monitored by a spectrophotometer, and 1 unit of the enzyme activity was designated as the enzyme amount that reduced $1 \mathrm{nmol}$ of NADP per min.

Polyacrylamide gel electrophoresis. Polyacrylamide gel electrophoresis was carried out, and farnesol dehydrogenase activity was located in the gel by staining in the dark at $25^{\circ} \mathrm{C}$ in $5 \mathrm{ml}$ of $20 \mathrm{~mm}$ potassium phosphate buffer ( $\mathrm{pH} 8.0$ ) containing $2 \mathrm{~mm} t, t$-farnesol, $0.25 \mathrm{~mm}$ NADP, $0.01 \%$ of phenazine methosulfate, and $0.01 \%$ of $p$ nitroblue tetrazolium. Protein staining was done by Coomasie brilliant blue $\mathrm{R}$.

Determination of protein content. Protein content was determined by the method of Lowry et al. ${ }^{17)}$

Determination of furano-sesquiterpenoid content. Furanosesquiterpenoid content in the infected region was determined by the method of Hyodo et al. ${ }^{18)}$

\section{RESULTS}

\section{Occurrence of farnesol dehydrogenase in di- seased tissue}

The crude enzyme solution from diseased tissue was incubated at $30^{\circ} \mathrm{C}$ with shaking for $60 \mathrm{~min}$ with $2.5 \mathrm{mM} t, t$-farnesol in $0.6 \mathrm{ml}$ acetone, $1 \mathrm{~mm} \mathrm{NADP}$, and $10 \mathrm{~mm} \mathrm{NaF}$ in $15 \mathrm{ml}$ of total volume. The reaction was stopped by adding $15 \mathrm{ml}$ acetone, and $n$-hexane $(15 \mathrm{ml})$ was shaked with the mixture. The upper layer was evaporated in vacuo yielding an oily substance, which was applied to TLC plates and separately developed by $n$-hexane-EtOAc 
(9:1) and $\mathrm{CHCl}_{3}$-ethyl ether $(19: 1)$. In each case, one spot was detected on the TLC plate by UV-absorption under a UV-lamp, and by a positive reaction with 2,4-dinitrophenylhydrozine. Furthermore, the $R f$ values (the former, 0.96; the latter, 0.87) coincided with those of the authentic $t, t$-farnesal. When $c, t$ farnesol was used as the substrate, $c, t$-farnesal was proven to be the reaction product by the same procedures. Thus, it was demonstrated that farnesol dehydrogenase occurred in diseased tissue.

\section{Purification of farnesol dehydrogenase}

DE-52 column chromatography easily separated NADP-dependent farnesol dehydrogenase from NAD-dependent alcohol dehy-

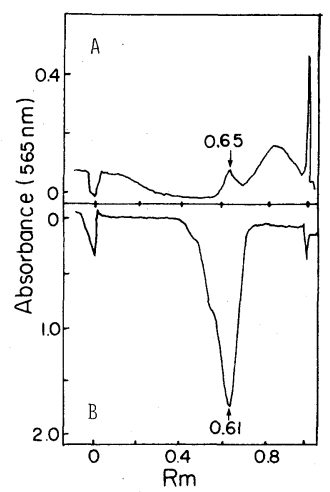

FIG. 1. Polyacrylamide Gel Zymograms of Farnesol Dehydrogenase Preparation from Diseased Sweet Potato.

A and B: The zymograms shown by a densitometer on activity staining and protein staining, respectively. The methods are described in Materials AND Methods. The peaks at $\mathrm{Rm} 0.65$ in $\mathrm{A}$ and 0.61 in $\mathrm{B}$ indicate farnesol dehydrogenase. The peak at Rm 0.82 in A shows DTT, which was stained non-enzymatically. drogenase, which was eluted first by passing the buffer alone as the initial step (see Materials and Methods). As shown in Table I, NADP-dependent farnesol dehydrogenase was purified about 1000 fold by ammonium sulfate salting-out, DE-52 chromatography, Toyopearl permeation chromatography, and $2^{\prime}, 5^{\prime}$-ADP Sepharose 4B affinity chromatography, and the yield was about $15 \%$. According to the polyacrylamide zymograms of the final sample, one sharp peak of enzyme staining appeared and accorded with the main stained protein band, which was accompanied by two faint bands (see Fig. 1). Thus, this sample was regarded as the almost purified enzyme and used for the characterization of the enzyme.

\section{Molecular weight and subunits}

The molecular weight of the enzyme was calculated from the straight line obtained by several marker proteins using Toyopearl HW60 (S) permeation chromatography (see Fig. 2), and estimated to be 90,000 . According to the SDS-polyacrylamide gel electrophoresis, one strong band appeared accompanied by two faint bands, and the former was regarded as the subunit of the enzyme, and the molecular weight was estimated to be 47,000 , using six marker proteins. Thus, the enzyme was concluded to consist of two identical subunits.

\section{The effect of $\mathrm{pH}$ on the activity}

The enzyme activity toward the NADPHgenerating reaction inclined to be high on the alkaline side, and the optimum $\mathrm{pH}$ was above pH 9.5 (Fig. 3). The enzyme activity in the

Table I. Purification of Farnesol Dehydrogenase from Diseased Tissue

\begin{tabular}{lrrrrr}
\hline \multicolumn{1}{c}{ Step } & $\begin{array}{c}\text { Protein } \\
(\mathrm{mg})\end{array}$ & $\begin{array}{c}\text { Total } \\
\text { activity } \\
\text { (units) }\end{array}$ & $\begin{array}{r}\text { Specific } \\
\text { activity } \\
\text { (units/mg) }\end{array}$ & $\begin{array}{r}\text { Yield } \\
(\%)\end{array}$ & Fold \\
\hline Sephadex G-25 chromatography and centrifugation & 412.80 & 7.430 & 0.018 & 100.0 & 1.0 \\
$\left(\mathrm{NH}_{4}\right)_{2} \mathrm{SO}_{4} 40 \sim 65 \%$ saturation & 111.00 & 4.773 & 0.043 & 62.5 & 2.4 \\
DE-52 chromatography & 7.43 & 2.080 & 0.280 & 27.1 & 15.6 \\
Toyopearl permeation chromatography & 1.52 & 1.687 & 1.110 & 17.3 & 61.7 \\
2',5'-ADP Sepharose 4B affinity chromatography $^{\prime}$ (und & 0.06 & 1.101 & 18.342 & 14.5 & 1019.0 \\
\hline
\end{tabular}




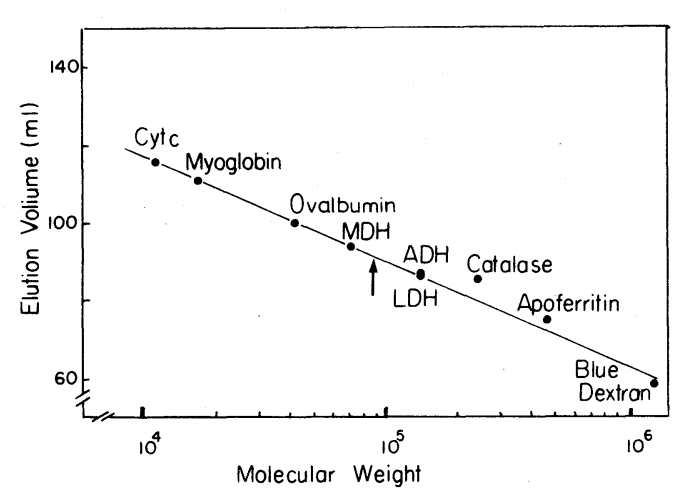

FIG. 2. Determination of the Molecular Weight of Farnesol Dehydrogenase by Toyopearl Permeation Chromatography.

Marker Proteins: cytochrome $c$ from horse heart (Cyt $c$, $11,700)$, myoglobin from equine skeletal muscle $(17,200)$, ovalbumin from hen's egg $(43,000)$, malate dehydrogenase from pig heart $(\mathrm{MDH}, 70,000)$, lactate dehydrogenase from beef muscle (LDH, 140,000), alcohol dehydrogenase from yeast $(\mathrm{ADH}, 140,000)$, catalase from beef liver $(240,000)$, and apoferritin from horse spleen $(460,000)$. Elution solvent: $20 \mathrm{~mm}$ potassium phosphate buffer $(\mathrm{pH}$ 8.0) containing $0.2 \mathrm{M} \mathrm{KCl}$ and $1 \mathrm{~mm}$ DTT. Elution was performed at $4^{\circ} \mathrm{C}$ and at the rate of $1 \mathrm{ml}$ per min, and the detection was carried out by the absorbance at $280 \mathrm{~nm}$.

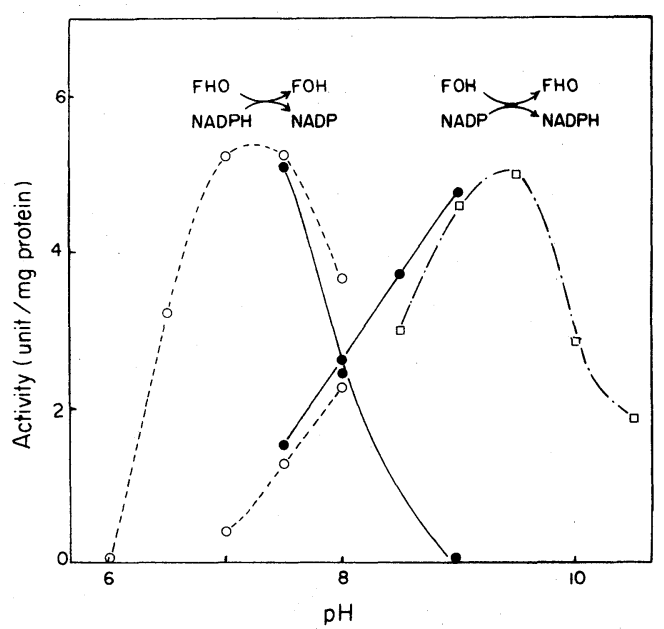

FIG. 3. Effect of $\mathrm{pH}$ on the Activity of Farnesol Dehydrogenase.

Right and left sides: NADPH generating reaction and the reverse reaction, respectively.

$\bigcirc--\bigcirc, \quad-\bigcirc$ and $\square-\cdot-\square$ : potassium phosphate buffer $(\mathrm{pH}$ 6.0 8.0), Tris- $\mathrm{HCl}$ buffer ( $\mathrm{pH} 7.5 \sim 9.0$ ) and $\mathrm{NH}_{4} \mathrm{OH}-\mathrm{HCl}$ buffer ( $\mathrm{pH} 8.5 \sim 10.5$ ), respectively.

FOH and FHO: farnesol and farnesal, respectively. reverse reaction, however, appeared high in the neutral range, and the optimum $\mathrm{pH}$ was 7.0 to 7.5 .

\section{Substrate specificity}

NADP was absolutely required for the activity, and NAD could not be substituted for NADP. Various kinds of alcohol were tested for the activity. The maximum activity was given when $t, t$-farnesol was used and the activity was decreased in the following order (Table II): $c, t$-farnesol $\left(\mathrm{C}_{15}\right)>$ geraniol $\left(\mathrm{C}_{10}\right)$ $>$ citronerol $\left(\mathrm{C}_{10}\right)>$ nerol $\left(\mathrm{C}_{10}\right)>$ decanol $\left(\mathrm{C}_{10}\right)$. Benzylalcohol, glycerol and ethanol showed no activity. This enzyme was capable of oxidizing $\mathrm{C}_{15}$ - to $\mathrm{C}_{10}$-isoprenoid and aliphatic components. The $K m$ value for $t, t$ farnesol was $15.6 \mu \mathrm{M}$, but that for geraniol was $729.0 \mu \mathrm{M}$. Thus, this enzyme is reasonably cal-

Table II. Substrate Specificity of Farnesol Dehydrogenase from Diseased Tissue

\begin{tabular}{lccc}
\hline \multicolumn{1}{c}{$\begin{array}{c}\text { Substrate } \\
(0.3 \mathrm{mM})\end{array}$} & $\begin{array}{c}\text { Activity } \\
\text { (units) }\end{array}$ & $\begin{array}{c}\text { Relative } \\
\text { activity } \\
(\%)\end{array}$ & $\begin{array}{c}K m \\
(\mu \mathrm{M})\end{array}$ \\
\hline trans, trans-Farnesol & 1.25 & 100.0 & 15.6 \\
cis, trans-Farnesol & 1.04 & 83.2 & - \\
Geraniol & 0.72 & 57.6 & 729.0 \\
Citronerol & 0.47 & 37.6 & - \\
Nerol & 0.45 & 36.0 & - \\
Decanol & 0.12 & 9.6 & - \\
Benzylalcohol & 0.00 & 0.0 & - \\
Glycerol & 0.00 & 0.0 & - \\
Ethanol & 0.00 & 0.0 & - \\
\hline
\end{tabular}

TABlE III. EFFECT OF INHIBITORS ON FARNESOL Dehydrogenase Activity

DTT was contained in the enzyme sample, but the concentration $\left(3.3 \sim 6.6 \times 10^{-6} \mathrm{mM}\right)$ was negligible compared to those of the above reagents.

\begin{tabular}{lcr}
\hline \multicolumn{1}{c}{$\begin{array}{c}\text { Reagent } \\
(\mathrm{mM})\end{array}$} & $\begin{array}{c}\text { Activity } \\
\text { (units) }\end{array}$ & $\begin{array}{c}\text { Inhibition } \\
(\%)\end{array}$ \\
\hline $\mathrm{N}$-Ethylmaleimide $(0.05)$ & 0.00 & 100.0 \\
$\mathrm{ICH}_{2} \mathrm{CONH}_{2}(0.05)$ & 0.74 & 28.8 \\
$\mathrm{CuCl}_{2}(0.05)$ & 0.00 & 100.0 \\
$\mathrm{ZnCl}_{2}(0.05)$ & 0.00 & 100.0 \\
$\mathrm{MgCl}_{2}(1.00)$ & 1.02 & 1.9 \\
$\mathrm{EDTA}_{\mathrm{H}}(3.33)$ & 0.53 & 49.0 \\
$\mathrm{H}_{2} \mathrm{O}$ & 1.04 & 0.0 \\
\hline
\end{tabular}


led NADP-dependent farnesol dehydrogenase.

\section{The effect of inhibitors on the activity}

The activity was inhibited by some $\mathrm{SH}$ group inhibiting reagents such as $\mathrm{N}$ ethylmaleimide, monoiodoacetamide, $\mathrm{CuCl}_{2}$, and $\mathrm{ZnCl}_{2}$ at relatively low concentrations, indicating that the SH-group in farnesol dehydrogenase participated in its activity. EDTA also inhibited the enzyme activity to some extent, which suggests the participation of some metal ions in the activity (see Table III).

Changes in the activity of farnesol dehydrogenase in response to black rot fungus infection and cut injury

In response to black rot fungus infection and cut injury, the activity of farnesol dehydrogenase was increased, although a little activity was detected in fresh tissue without incubation. With infection, the activity increased with a lag of several hr and reached a plateau 2 days after the inoculation. With cut

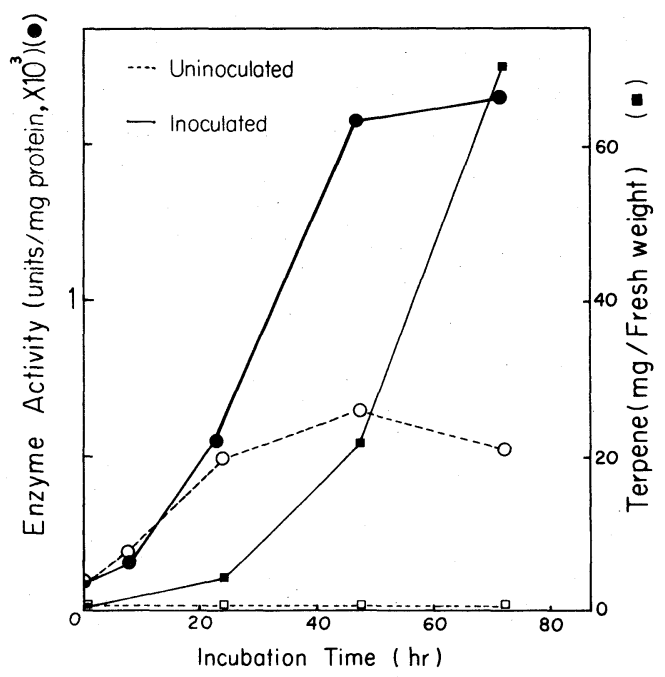

FIG. 4. Changes in the Activity of Farnesol Dehydrogenase and the Content of Furano-sesquiterpenoids in Response to Black Rot Fungus Infection or Cut Injury.

- and $\bigcirc--\bigcirc$ : the activity of farnesol dehydrogenase in black rot fungus-infected and cut-injured tissues, respectively.

- $\square$ and $\square--\square$ : the content of furano-sesquiterpenoids in black rot fungus-infected and cut-injured tissues. injury, the activity was increased at a similar level until 1 day of incubation, thereafter reaching a plateau. Following the increase in the activity, furano-sesquiterpenoids were produced in diseased tissue. However, these were not detected at any time in cut-injured tissue (see Fig. 4).

\section{DISCUSSION}

There are many reports on terpene alcohol dehydrogenases in higher plants. Among them, an NADP-dependent farnesol dehydrogenase has been reported to be present in orange flavedo. ${ }^{19)}$ However, the report showed only the presence of this enzyme, but did not describe the purification and characteristics. On the other hand, NADP-dependent geraniol dehydrogenase was detected in orange juice vesicles, ${ }^{20)}$ and actively oxidized some monoterpene alcohols in the presence of NADP, and at a slower rate farnesol, too. The behavior of this enzyme with $\mathrm{pH}$ and inhibitors resembled those of the sweet potato enzyme. Furthermore, another report ${ }^{21)}$ described the dehydrogenation of borneol, a cyclic-monoterpene alcohol, by NADP-dependent dehydrogenase isolated from sage. However, this was different from the NADP-dependent monoterpene alcohol dehydrogenases in orange in several enzymatic features. NADP-dependent alcohol dehydrogenase samples were isolated from tea seeds ${ }^{22}$ and strawberry seeds ${ }^{23)}$ and enzymatically characterized. The natures of the latter were similar to those of the sweet potato enzyme, although the substrate specificity was not exactly the same, and the capability of oxidizing farnesol was not investigated in both seed enzymes.

It was demonstrated that furanosesquiterpenoids such as ipomeamarone, ${ }^{1,2)}$ dehydroipomeamaron $\mathrm{e}^{13)}$ and ipomeamaronol $^{14,15)}$ were converted from farnesol, ${ }^{9,12,24)}$ which were produced by the mevalonate pathway, ${ }^{7,8)}$ in diseased sweet potato root tissue. Thus, to elucidate the initial reaction of the conversion of farnesol to furano-sesquiterpenoids should be important. One possi- 
bility may be the production of farnesal by NADP-dependent farnesol dehydrogenase. Recently, Burka et al. ${ }^{12)}$ found the occurrence of 9-hydroxyfarnesol in $\mathrm{HgCl}_{2}$-treated sweet potato. Hence, the above enzyme may participate in the conversion of 9-hydroxyfarnesol to 9-hydroxyfarnesal, in the alternative way. Since the enzyme is formed especially in response to black rot fungus infection, it is very likely that the enzyme is involved in the formation of the furano-ring in furano-sesquiterpenoids as mentioned above.

Acknowledgments. The authors wish to express their thanks to Dr. K. Imai, Laboratory of Organic Chemistry, Faculty of Agriculture, Nagoya University for advising on the preparation of $t, t$-farnesal.

\section{REFERENCES}

1) H. Hiura, Rep. Gifu Agr. Coll., 50, 1 (1943).

2) T. Kubota and T. Matsuura, J. Chem. Soc. Jpn., 74, 101, 197, 248, 668 (1952).

3) T. Akazawa, Arch. Biochem. Biophys., 90, 82 (1960).

4) I. Uritani, "Biochemistry of Plant Phenolic Substances," ed. by Gestur Johnson and T. A. Geissman, Colorado State University Press, Colorado, 1962, pp. 99 124.

5) I. Uritani, S. Suzuki and K. Muramatsu, Agr. and Hort. (in Japanese), 22, 515 (1947).

6) M. Kojima and I. Uritani, Physiol Plant Pathol., 8, 97 (1976).

7) H. Suzuki, K. Oba and I. Uritani, Agric. Biol. Chem., 38, 2053 (1974).
8) K. Oba, H. Tatematsu, K. Yamashita and I. Uritani, Plant Physiol., 58, 51 (1976).

9) I. Oguni and I. Uritani, Plant Cell Physiol., 12, 507 (1971).

10) H. Inoue and I. Uritani, Agric. Biol. Chem., 44, 2245 (1980).

11) M. Fujita, K. Oba and I. Uritani, Agric. Biol. Chem., 45, 1911 (1981).

12) L. T. Burka, L. J. Felice and S. W. Jackson, Phytochemistry, 20, 647 (1981).

13) I. Oguni and I. Uritani, Plant Physiol., 53, 649 (1974).

14) N. Kato, H. Imaseki, N. Nakashima and I. Uritani, Tetrahedron Lett., 843 (1971).

15) D. T. D Yang, B. J. Wilson and T. M. Harris, Phytochemistry, 10, 1653 (1971).

16) E. J. Corey, N. W. Gilman and B. E. Ganem, J. Am. Chem. Soc., 90, 5616 (1968).

17) O. H. Lowry, N. J. Rosebrough, A. L. Farr and R. J. Randall, J. Biol. Chem., 193, 265 (1951).

18) H. Hyodo, I. Uritani and S. Akai, Phytopathol. Z., 65, 332 (1969).

19) L. Chayet, R. Pont-Lazica, C. George-Nascimento and O. Cori, Phytochemistry, 12, 95 (1973).

20) V. H. Potty and J. H. Bruemmer, Phytochemistry, 9, 1001 (1970).

21) R. Croteau, C. L. Hooper and M. Felton, Arch. Biochem. Biophysic., 188, 182 (1978).

22) J. Sekiya, W. Kawasaki, T. Kajiwara and A. Hatanaka, Agric. Biol. Chem., 39, 1677 (1975).

23) I. Yamashita, K. Iino and S. Yoshikawa, Agric. Biol. Chem., 42, 1125 (1978).

24) I. Uritani, K. Oba, A. Takeuchi, K. Sato, H. Inoue, R. Ito and I. Ito, "Antinutrients and Natural Toxicants in Foods," ed. by R. L. Ory, Food \& Nutrition Press, Inc., Westport, Connecticut, 1981, pp. $1 \sim 16$. 